\title{
Оценка влияния полиморфизма гена рецептора витамина D A283G на тяжесть менопаузальных расстройств и качество жизни постменопаузальных женщин города Екатеринбурга
}

\author{
Вихарева А. А. ${ }^{1}$, Сафьяник E. А. ${ }^{1}$, Изможерова Н. В. ${ }^{1}$, Попов А. А. ${ }^{1}$, Рябинина А. В. ${ }^{2}$ \\ 1 - ФГБОУВО «Уральский государственный медицинский университет» \\ Министерства Здравоохранения Российской Федерации, Россия, Екатеринбург \\ ${ }^{2}$ - ФГБУН «Институт высокотемпературной электрохимии» Уральского отделения Российской академии наук, \\ Россия, Екатеринбург
}

Ключевые слова: полиморфизм генов; витамин Д; менопаузальные расстройства; постменопауза; качество жизни

\section{Для цитирования:}

Вихарева А. А., Сафьяник Е. А., Изможерова Н. В., Попов А. А., Рябинина А. В. Оценка влияния полиморфизма гена рецептора витамина D A283G на тяжесть менопаузальных расстройств и качество жизни постменопаузальных женщин города Екатеринбурга. Фармакогенетика и фармакогеномика. 2021;(2):4-5. (In Russ). https://doi.org/10.37489/2588-0527-2021-2-4-5

\section{Введение}

Существование более 50 метаболитов витамина D, прямое и опосредованное их действие на ген рецептора витамина D $(V D R)$ определяет уникальность D-гормона в отношении не только костных, но и внекостных эффектов [1]. Для гена рецептора витамина D (VDR) характерен генетический полиморфизм, то есть существование различных аллельных вариантов этого гена в популяции [2]. Предполагается, что полиморфные варианты могут быть причиной как снижения, так и повышения функции витамина D. Одним из наиболее значимых полиморфизмов гена $V D R$, модулирующих биологические эффекты витамина D, является A283G (BsmI). Показано, что полиморфный вариант BsmI связан с активностью или экспрессией $V D R$, что может оказывать влияние на прямые и плейотропные эффекты витамина D [3].

\section{Цель}

Оценить частоту выявления полиморфных маркеров гена $V D R$ A283G (rs1544410) и обеспеченность 25(OH)D в популяции женщин поздней постменопаузы, проживающих в городе Екатеринбурге. Установить возможный генетический вклад в выраженность менопаузальных расстройств и качество жизни женщин.

\section{Материалы и методы}

В настоящем одномоментном исследовании приняло участие 100 женщин в возрасте от 57 до 79 лет в поздней постменопаузе, самостоятельно проживающих в г. Екатеринбурге. Методом полимеразной цепной реакции в режиме реального времени определены полиморфные маркеры гена VDR A283G (AA/AG/GG). Материалом для выделения ДНК служила венозная кровь. Концентрация 25(OH)D определялась методом электрохемилюминесцентного иммуноанализа (ECLIA). Выраженность менопаузальных расстройств оценивали с помощью модифицированного менопаузального индекса (ММИ) [4]. Качество жизни оценивалось с помощью опросника SF-36v2 [5], данные представлены по 10 шкалам: физическое функционирование (ФФ); ролевое функционирование, обусловленное физическим состоянием (РФФ); физическая боль (Б); общая оценка здоровья (О3); жизненная активность (Ж); социальное функционирование (СФ); ролевое функционирование, обусловленное эмоциональным состоянием (РФЭ); психическое здоровье (ПЗ); физический компонент здоровья (ФКЗ); психологический компонент здоровья (ПКЗ).

Статистическая обработка данных проводилась с помощью программного пакета Statistica 13.0. Учитывая, что характер распределения не соответствует нормальному, для сравнения несвязанных совокупностей использовался критерий Манна-Уитни. В выборках рассчитаны медианы, 25-й, 75-й процентили. Различия данных считались статистически значимыми при значениях $p<0,05$. Исследование одобрено локальным этическим комитетом ФГБОУ ВО УГМУ Минздрава РФ 19.10.2018 г. 


\section{Результаты}

Генотип GG полиморфного маркера BsmI гена VDR определён у $40 \%$ обследованных, AG - у $47 \%$, $\mathrm{AA}$ - в $13 \%$ случаев. Аллель $\mathrm{G}$ встречалась в $63,5 \%$, аллель А - в $36,5 \%$ случаев. Адекватный уровень $25(\mathrm{OH})$ D установлен в $17 \%$, недостаточность - в $37 \%$ и дефицит - в $46 \%$ случаев, в том числе тяжёлый дефицит в $4 \%$. Медианы концентрации 25(OH)D составили 16,2 нг/мл $(13,9 ; 21,59), 22,3$ нг/мл $(17,5 ; 29,7)$ и 20,0 нг/мл $(15,1 ; 24,8)$ у женщин с AA-генотипом, AG-генотипом и GG-генотипами, соответственно. Статистические различия в отношении обеспеченности $25(\mathrm{OH}) \mathrm{D}$ установлены для AA и $\mathrm{AG}$ генотипов полиморфного маркера BsmI гена VDR $(p=0,03)$.

Сравнение выраженности менопаузальных расстройств и качества жизни в 2 группах - AА-генотип и $\mathrm{AG}$-генотип (группа $1, n=60$ ) и $\mathrm{GG}$-генотип (группа 2, $n=40$ ) выявило более высокие показатели тяжести менопаузальных расстройств в группе 1 по сравнению с группой $2: 14$ баллов $(9 ; 16)$ против $11,5(8,5 ; 16,5)$ по нейровегетативным симптомам ( $p=0,34) ; 7$ баллов $(5 ; 9)$ против $6(4 ; 7,5)$ по обменно-эндокринным симптомам $(p=0,01) ; 10$ баллов $(8 ; 12,5)$ против $7,5(5,5 ; 10,5)$ по психоэмоциональным симптомам $(p=0,03)$; 31 балл $(23 ; 36,5)$ против $25,5(19,5 ; 33,0)$ по суммарному ММИ $(p=0,02)$.

Оценка качества жизни выявила значимо более низкие показатели в группе 1: ФФ - 70 баллов $(50 ; 80)$ и $70(57,5 ; 85)$; РФФ - 50 баллов $(37,5 ; 75)$ и $53,1(46,8 ; 75)$; Б - 50 баллов $(41 ; 62)$ и $56,5(41 ; 72,5)$; О3 - 45 баллов $(40 ; 55)$ и $47,5(38,5 ; 61) ;$ Ж -50 баллов $(40 ; 50)$ и $55(40 ; 60)$; СФ - 62,5 балла $(50 ; 75)$ и $75(50 ; 87,5)$; РФЭ - 58,3 балла $(50 ; 75)$ и $70,8(50 ; 87,4)$; П3 - 56 баллов $(48 ; 64)$ и $60(48 ; 72)$; ФК 3 - 41,2 балла $(35,1 ; 45,1)$ и 43,3 $(35,4$; $46,2)$; ПК 3 - 41,5 балла $(37,7 ; 46,6)$ и $44,6(39,5 ; 51,5)$ в группе 1 и 2 , соответственно. Статистически значимые различия выявлены по шкале Б $(p=0,02)$, по остальным шкалам различия не были значимыми $(p>0,05)$.

\section{Заключение}

В популяции жительниц г. Екатеринбурга в поздней постменопаузе преобладают AG и GG-генотипы полиморфного маркера BsmI гена VDR A283G (rs1544410), в то время как AА генотип встречается лишь в $13 \%$ случаев. Высоко распространены недостаточность и дефицит концентрации 25(OH)D сыворотки крови, а оптимальную обеспеченность имеют лишь 17 \% пациенток. АА-генотип ассоциирован со сниженной обеспеченностью 25(OH)D. Женщины, имеющие GG-генотип полиморфного маркера BsmI, отмечают меньшую выраженность менопаузальных расстройств и демонстрируют лучшие показатели качества жизни (в частности, меньшую интенсивность боли, способной ограничивать повседневную активность). Полученные данные требуют дальнейших исследований, учитывая возможную проективную роль $\mathrm{G}$ аллели в отношении менопаузальных расстройств и качества жизни пациенток поздней постменопаузы.

\section{Список литературы / References}

1. Громова О.А., Торшин И.Ю. Витамин D - Смена парадигмы. - М.: ГЭОТАР-Медиа; 2021. - 736 c. [Gromova OA, Torshin IYu. Vitamin D Smena paradigmy. Moscow: GEOTAR-Media; 2021. (In Russ).]. DOI: 10.33029/9704-5787-0-VDPS-2021-1-736.

2. Uitterlinden AG, Fang Y, Van Meurs JB et al. Genetics and biology of vitamin D receptor polymorphisms. Gene. 2004;338(2):143-156. DOI: 10.1016/ j.gene.2004.05.014.

3. Palomba S, Orio F Jr, Russo T et al. BsmI vitamin D receptor genotypes influence the efficacy of antiresorptive treatments in postmenopausal osteoporotic women. A 1-year multicenter, randomized and controlled trial. Osteoporos Int. 2005;16(8): 943-952. DOI: 10.1007/s00198-004-1800-5.

4. Сметник В.П., Ткаченко Н.М., Глезер Г.А., Москаленко Н.П. Климактерический синдром. - М.: Медицина; 1988. [Smetnik VP, Тkachenko NM, Glezer GA, Moskalenko NP. Klimaktericheskij sindrom. Moscow: Medicina; 1988. (In Russ).].

5. Brazier JE, Harper R, Jones NM et al. Validating the SF-36 health survey questionnaire: new outcome measure for primary care. BMJ. 1992;305(6846): 160-164. DOI: 10.1136/bmj.305.6846.160. 